\title{
PENGARUH DASAR KARIR (CARRIER ANCHOR) TERHADAP PERENCANAAN KARIR MAHASISWA JURUSAN PENDIDIKAN EKONOMI ANGKATAN 2013 SEBAGAI GURU
}

\author{
Putu Ayu Desy Pangastuti \\ Jurusan Pendidikan Ekonomi, Fakultas Ekonomi \\ Universitas Pendidikan Ganesha Singaraja, \\ Indonesia \\ email :desyayu20@gmail.com
}

\begin{abstract}
ABSTRAK
Tujuan penelitian ini adalah untuk mengetahui (1) pengaruh dasar karir (carrier anchor) dilihat dari kemampuan manajerial terhadap perencanaan karir mahasiswa, (2) pengaruh dasar karir dilihat dari kemampuan teknis terhadap perencanaan karir mahasiswa, (3) pengaruh dasar karir dilihat dari keamanan terhadap perencanaan karir mahasiswa, (4) pengaruh dasar karir dilihat dari kreativitas terhadap perencanaan karir mahasiswa, dan (5) pengaruh dasar karir dilihat dari kebebasan terhadap perencanaan karir mahasiswa Jurusan Pendidikan Ekonomi angkatan 2013 sebagai guru. Penelitian ini adalah jenis penelitian kausal. Data dikumpulkan dengan metode kuesioner. Subjek penelitian adalah mahasiswa Jurusan Pendidikan Ekonomi angkatan 2013. Objek penelitian ini adalah dasar karir (carrier anchor) dan perencanaan karir. Data dianalisis menggunakan analisis regresi sederhana. Hasil penelitian menunjukkan bahwa bahwa: (1) tidak ada pengaruh positif dan signifikan dasar karir (carrier anchor) dilihat dari kemampuan manajerial terhadap perencanaan karir mahasiswa, (2) tidak ada pengaruh signifikan dasar karir dilihat dari kemampuan teknis terhadap perencanaan karir mahasiswa, (3) tidak ada pengaruh signifikan dasar karir dilihat dari keamanan terhadapa perencanaan karir mahasiswa, (4) tidak ada pengaruh signifikan dasar karir dilihat dari kreativitas terhadap perencanaan karir mahasiswa, dan (5) ada pengaruh signifikan dasar karir dilihat dari kebebasan terhadap perencanaan karir mahasiswa.
\end{abstract}

Kata kunci: dasar karir dan perencanaan karir.

\begin{abstract}
Research aims to understand influence (1) carrier anchor seen from managerial capability to the college's student carrier plan (2) carrier anchor seen from technical capabilities to the college's student carrier plan (3) carrier anchor seen from savety to the college's student carrier plan (4) carrier anchor seen from creativity to the college's student's carrier plan and (5) carrier anchor seen from freedom to the college's student's carrier plan. The research is the kind of research causal. Data were collected with the questionnaire. The subject of study is Economic education department's students in year 2013. The studi's objects are carrier anchor and college's student carrier plan. The data analyzed with regression. The result show that (1) there is no impact carrier anchor seen from managerial ability to the college's student carrier plan (2) there is no impact carrier anchor seen from tecnical ability to the college's student carrier plan (3) there is no impact carrier anchor seen from savety to the college's student carrier plan (4) there is no impact carrier anchor seen from creativity to the college's student carrier plan and (5) any impact carrier anchor seen from freedom to the college's students carrier plan.
\end{abstract}

Key words: carier anchor and carrier plan 


\section{PENDAHULUAN}

Karir merupakan masalah penting yang harus dihadapi oleh semua orang. Hal ini dikarenakan karir sangat berdampak pada masa depan seseorang. Seseorang yang berhasil dalam menekuni karirnya maka akan memperoleh masa depan yang cerah sedangkan sesorang yang mengalami kemandegan dalam karirnya maka akan menemui kesulitan di kemudian hari. Karir merupakan perjalanan pekerjaan seorang pegawai dalam sebuah organisasi (Sugiarto, 2007:120).

Berhasilnya seseorang untuk dapat menekuni sebuah karir yang telah mereka pilih juga dipengaruhi oleh perencanaan karir yang mereka lakukan. Seseorang akan lebih mudah dalam berkarir apabila telah matang dalam perencanaan karirnya. Dengan perencanaan karir yang matang maka seseorang akan mudah untuk menjalani karir yang mereka pilih. Hal ini dikarenakan dalam proses perencanaan karir setiap orang akan mempersiapkan diri mereka untuk memenuhi syarat dan kriteria yang diperlukan dalam karir yang mereka pilih untuk di jalani (Sugiarto, 2007:129).

Pada dasarnya terdapat dua faktor yang mempengaruhi perencanaan karir seseorang yakni faktor dasar karir (carrier anchor) dan tahap kehidupan karir (carrier life stage) (Sedarmayanti, 2013:123). Menurut Edgar Schein dalam Dessler (2000:555) dasar karir merupakan motif yang mendasari seseorang untuk memilih suatu karir. Terdapat lima motif yang ada dalam dasar karir yakni, kemampuan manajerial, kemampuan teknis, keamanan, kreativitas dan kebebasan. Perencanaan karir merupakan proses seseorang memilih sasaran karir dan jalur yang digunakan untuk mencapai sasaran tersebut (Sedarmayanti, 2013:212).

Perencanaan sebuah karir juga sangat penting untuk dilakukan oleh para mahasiswa. Perencanaan karir ini akan mempermudah mahasiswa untuk menapaki sebuah karir nantinya. Ini dikarenakan dalam merencanakan karir mahasiswa akan mempersiapkan diri untuk memenuhi standar dan kualifikasi yang diinginkan dari masing-masing karir tersesebut. Persiapan diri dalam perencanaan karir ini salah satunya diperoleh dari pemilihan pendidikan. Bagi mahasiswa yang ingin menapaki karir sebagai seorang guru maka mereka akan memilih Jurusan keguruan dengan ketentuan minimal strata 1 (S1) sesuai dengan isi Undang-Undang No.14 Tahun 2005 yang mengatur tentang Guru dan Dosen.

Universitas Pendidikan Ganesha (UNDIKSHA) adalah salah satu perguruan tinggi negeri yang membuka Jurusan keguruan yang. Salah satu Jurusan keguruan yang dibuka oleh UNDIKSHA adalah Jurusan Pendidikan Ekonomi yang berada dibawah naungan Fakultas Ekonomi (FE). Jurusan Pendidikan Ekonomi merupakan Jurusan tertua dan satusatunya jurusan keguruan yang ada dibawah naungan FE. Jurusan Pendidikan Ekonomi membekali mahasiswa dengan empat kompetensi yang wajib dimiliki oleh seorang guru guna mempersiapkan mereka sebagai guru professional. Kompetensi yang dimaksud adalah kompetensi pedagogik, kompetensi kepribadian, kompetensi profesional dan kompetensi sosial.

$\begin{array}{ccr}\text { Bagi mahasiswa Jurusan } & \begin{array}{r}\text { manomidikan } \\ \text { Ekonomi yang telah }\end{array}\end{array}$ menyelesaikan pendidikan jenjang $S 1$ idealnya akan berkarir sebagai guru sesuai dengan kualifikasi akademik serta sertifikat pendidik yang dimiliki. Dalam Buku Pedoman Studi Fakultas Ekonomi dimuat bahwa profil lulusan Jurusan Pendidikan Ekonomi adalah wirausaha dalam bidang pendidikan/pelatihan, tenaga kependidikan ekonomi dan pengkaji pendidikan ekonomi. Namun dari observasi yang dilakukan oleh penulis pada mahasiswa Jurusan Pendidikan Ekonomi angkatan 2009-2011 yang telah menyelesaikan masa pendidikan, dari 100 orang lulusan didapatkan hanya $32 \%$ orang dari alumni yang berkarir sebagai guru, $41 \%$ memilih berkarir dibidang keuangan, perkantoran serta lembaga pemerintah non pendidikan, $23 \%$ sedang mencari pekerjaan dan 3\% membuka usaha sendiri. $\mathrm{Hal}$ ini menunjukan adanya perbedaan antara perencanaan karir saat masih menjadi mahasiswa dengan karir yang ditekuni setelah menyelesaikan pendidikan sebagai mahasiswa. 
peneliti $^{\text {Dari pemaparan diatas maka }}$ mengetahui dasar karir (carrier anchor) terhadap perencanaan karir mahasiswa sebagai guru menjadi dasar penelitian yang berjudul "Pengaruh Dasar Karir (Carrier Anchor) Terhadap Perencanaan Karir Mahasiswa Jurusan Pendidikan Ekonomi Angkatan 2013 Sebagai Guru".

Berdasarkan latar belakang masalah di atas maka yang menjadi rumusan permasalahan dalam penelitian ini adalahsebagai berikut. (1) Apakah ada pengaruh dasar karir (carrier anchor) dilihat dari kemampuan manajerial terhadap perencanaan karir mahsiswa Jurusan Pendidikan Ekonomi angkatan 2013 sebagai guru? (2) Apakah ada pengaruh dasar karir (carrier anchor) dilihat dari kemampuan teknis terhadap perencanaan karir mahsiswa Jurusan Pendidikan Ekonomi angkatan 2013 sebagai guru? (3) Apakah ada pengaruh dasar karir (carrier anchor) dilihat dari keamanan terhadap perencanaan karir mahsiswa Jurusan Pendidikan Ekonomi angkatan 2013 sebagai guru? (4) Apakah ada pengaruh dasar karir (carrier anchor) dilihat dari kreativitas terhadap perencanaan karir mahsiswa Jurusan Pendidikan Ekonomi angkatan 2013 sebagai guru? (5) Apakah ada pengaruh dasar karir (carrier anchor) dilihat dari kebebasan terhadap perencanaan karir mahsiswa Jurusan Pendidikan Ekonomi angkatan 2013 sebagai guru?

Sesuai dengan rumusan masalah di atas, maka yang menjadi tujuan penelitian ini adalah untuk mengetahui: (1) Pengaruh dasar karir (carrier anchor) dilihat dari kemampuan manajerial terhadap perencanaan karir mahsiswa Jurusan Pendidikan Ekonomi angkatan 2013 sebagai guru; (2) Pengaruh dasar karir (carrier anchor) dilihat dari kemampuan teknis terhadap perencanaan karir mahsiswa Jurusan Pendidikan Ekonomi angkatan 2013 sebagai guru; (3) Pengaruh dasar karir (carrier anchor) dilihat dari keamanan terhadap perencanaan karir mahsiswa Jurusan Pendidikan Ekonomi angkatan 2013 sebagai guru; (4) Pengaruh dasar karir (carrier anchor) dilihat dari kreativitas terhadap perencanaan karir mahasiswa Jurusan Pendidikan Ekonomi angkatan 2013 sebagai guru; (5) Pengaruh dasar karir (carrier anchor) dilihat dari kebebasan terhadap perencanaan karir mahsiswa Jurusan Pendidikan Ekonomi angkatan 2013 sebagai guru.

\section{METODE}

Penelitian ini merupakan jenis penelitian kausal. Penelitian kausal adalah penelitian yang menunjukkan hubungan variabel bebas dengan variabel terikat (Sangadji, 2010:22). Terdapat dua variabel yang digunakan dalam penelitian ini yaitu variabel bebas dan variabel terikat. Variabel bebas dalam penelitian ini adalah dasar karir yang memiliki lima dimensi yakni kemampuan manajerial, kemampuan fungsional, keamanan, kreativitas dan kebebasan. Sedangkan variabel terikat yang digunakan adalah perencanaan karir. Penelitian ini dilakukan guna mengetahui pengaruh yang diberikan oleh dasar karir dilihat dari segi kemampuan manajerial, kemampuan teknis, keamanan, kreatifitas dan kebebasan terhadap perencanaan karir mahasiswa khususnya di Jurusan Pendidikan Ekonomi. Analisis yang digunakan dalam penelitian ini adalah analisis regresi sederhana.

Subjek dalam penelitian ini adalah mahasiswa Jurusan Pendidikan Ekonomi angkatan 2013 dan objek dari penelitian ini adalah dasar karir dan perencanaan karir. Data yang digunakan dalam penelitian ini adalah data kuantitatif. Data ini berupa skor jawaban kuesioner yang diberikan oleh responden. Sumber data yang digunakan dalam penelitian ini adalah data primer, yaitu data yang diperoleh secara langsung terkait dengan pengaruh dasar karir (carrier anchor) terhadap perencanaan karir mahasiswa Jurusan Pendidikan Ekonomi angkatan 2013 sebagai seorang guru.

Metode pengumpulan data yang dipergunakan dalam penelitian ini adalah kuesioner. Metode kuesioner dipergunakan untuk memperoleh data dasar karir dan perencanaan karir mahasiswa Pogram Studi Ekonomi angkatan 2013 sebagai guru.

Dalam penelitian ini, analisis yang dipergunakan adalah analisis statistik dengan menggunakan analisis regresi 
linear sederhana. Regresi linear sederhana yaitu suatu metode statistik umum yang digunakan untuk meneliti hubungan antara sebuah variabel dependen dengan satu variabel independen. Untuk menyatakan layak atau tidaknya sebelum analisis regresi linier berganda maka terlebih dahulu dilakukanlah uji asumsi klasik. Uji asumsi klasik yang digunakan yaitu (1) uji multikolinearitas, (2) uji heterokedastistias, (3) uji normalitas, dan (4) uji autokorelasi, dimana uji multikolinearitas dilakukan untuk menguji apakah dalam model regresi ditemukan adanya korelasi yang tinggi atau sempurna antar variabel bebas. Akibat dari adanya multikolinearitas ini adalah kofisien regresinya tidak tertentu atau kesalahan standarnya tidak terhingga. Untuk mendeteksi apakah model regresi linier mengalami multikolinearitas dapat diperiksa menggunakan Variance Inflation Factor (VIF) jika nilai VIF kurang dari 10 dan nilai tolerance di atas 0,10 maka tidak terdapat gejala multikolineritas. Uji heteroskedastisitas bertujuan untuk menguji apakah model regresi terjadi ketidaksamaan variance dari risidual satu pengamatan ke pengamatan yang lain, atau disebut homoskedastisitas. Model regresi yang baik adalah tidak terjadi heteroskedastisitas. Uji ini dapat dilakukan dengan milihat gambar scatterplot antara nilai prediksi variabel bebas ZPRED ( nilai prediksi, sumbu $X$ ) dengan residualnya SRESID (nilai residualnya, sumbu $Y$ ). Apabila pada grafik tersebut tidak terdapat pola tertentu yang tratur dan data tersebar scara acak di atas dan di bawah angka 0 pada sumbu Y, maka diidentifikasi tidak terdapat heteroskedastisitas. Uji normalitas data dilakukan untuk menguji apakah dalam model regresi, variabel terikat dan variabel bebas memiliki distribusi normal atau tidak. Untuk menghindari terjadinya bias, data yang digunakan harus berdistribusi normal. Model regresi yang baik adalah memiliki data normal atau mendekati normal. Pengujian normalitas data dilakukan dengan menggunakan uji One Sample Klomogorov-Smirnov, dengan melihat tingkat signifikansi 5\%. Jika pengujian menghasilkan nilai signifikansi lebih besar dari 0,05 maka asumsi normalitas terpenuhi. Uji Autokorelasi digunakan untuk menguji apakah dalam sebuah model regresi linier terdapat korelasi antara kesalahan pengganggu pada periode $t$ dengan kesalahan pada periode $t-1$ (sebelumnya). Jika terjadi korelasi, maka dinamakan ada masalah autokorelasi. Untuk menguji Autokorelasi dapat dilihat dari nilai Durbin Waston (DW). Analisis data dilakukan dengan menggunakan bantuan program SPSS 16.0 for windows.

\section{HASIL PENELITIAN DAN PEMBAHASAN Hasil Penelitian}

Pengaruh dasar karir (carrier anchor) dilihat dari kemampuan manajerial terhadap perencanaan karir mahasiswa Jurusan Pendidikan Ekonomi angkatan 2013 sebagai guru dengan uji t menggunkan program SPSS 16.0 for windows. Adapun hasil analisis uji t dapat dilihat pada tabel 1.

Tabel 1 Hasil uji statistik toes kemampuan masnajerialterhadap perencanaan karir

\begin{tabular}{|c|c|c|c|c|c|}
\hline \multirow{2}{*}{ Model } & \multicolumn{2}{|c|}{ Coefficients } & \multirow{2}{*}{$\begin{array}{c}\text { Coefficients } \\
\text { Beta }\end{array}$} & \multirow[t]{2}{*}{$\mathrm{T}$} & \multirow[t]{2}{*}{ Sig. } \\
\hline & $B$ & Std. Error & & & \\
\hline 1 (Constant) & 10.634 & 2.054 & & 5.177 & .000 \\
\hline $\begin{array}{l}\text { Kemampuan } \\
\text { manajerial }\end{array}$ & .102 & .066 & .192 & 1.554 & .125 \\
\hline
\end{tabular}

Berdasarkan hasil perhitungan tabel diatas, menunjukan bahwa tidak ada pengaruh secara parsial yang signifikan dasar karir (charier anchor) dilihat dari kemampuan manajerial terhadap perencanaan karir mahasiswa Jurusan
Pendidikan Ekonomi Angkatan 2013 sebagai guru. Hal ini ditunjukkan dengan $t_{\text {hitung }}=1.554<t_{\text {tabel }}=1,669$ atau sig value $=$ $0,125>\alpha=0.05$. Nilai di atas menunjukkan bahwa dasar karir (carrier anchor) dilihat dari kemampuan manjerial tidak 
memberikan pengaruh terhadap perencanaan karir mahasiswa Jurusan Pendidikan Ekonomi Angkatan 2013 sebagai guru. Dengan demikian hipotesis pertama yang diajukan dalam penelitian ini tidak dapat diterima.
Pengaruh dasar karir (carrier anchor) dilihat dari kemampuan teknis terhadap perencanaan karir mahasiswa Jurusan Pendidikan Ekonomi angkatan 2013 sebagai guru dengan uji t menggunkan SPSS 16.0 for windows. Adapun hasil analisis uji $t$ dapat dilihat pada tabel 2 .

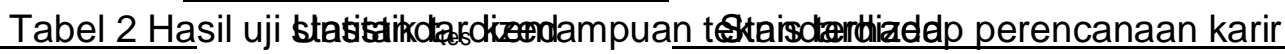

\begin{tabular}{|c|c|c|c|c|c|c|}
\hline \multirow{2}{*}{\multicolumn{2}{|c|}{ Model }} & \multicolumn{2}{|c|}{ Coefficients } & Coefficients & \multirow[t]{2}{*}{$\mathrm{T}$} & \multirow[t]{2}{*}{ Sig. } \\
\hline & & B & Std. Error & Beta & & \\
\hline 1 & (Constant) & 11.875 & 2.130 & & 5.576 & .000 \\
\hline & $\begin{array}{c}\text { Kemampuante } \\
\text { knis }\end{array}$ & .128 & .143 & .112 & .893 & .375 \\
\hline
\end{tabular}

Berdasarkan hasil perhitungan tabel di atas, menunjukan bahwa tidak ada pengaruh secara parsial yang signifikan dasar karir (charier anchor) dilihat dari kemampuan teknis terhadap perencanaan karir mahasiswa Jurusan Pendidikan Ekonomi angkatan 2013 sebagai guru. Hal ini ditunjukkan dengan thitung $=0.893<t_{\text {tabel }}$ $=1,669$ atau sig value $=0,375>\alpha=0.05$. nilai diatas menunjukkan bahwa dasar karir (carrier anchor) dilihat dari kemampuan teknis tidak memberikan pengaruh terhadap perencanaan karir mahasiswa Jurusan Pendidikan Ekonomi angkatan 2013 sebagai guru. Dengan demikian hipotesis kedua yang diajukan dalam penelitian ini tidak dapat diterima.

Pengaruh dasar karir (carrier anchor) dilihat dari keamanan terhadap perencanaan karir mahasiswa Jurusan Pendidikan Ekonomi angkatan 2013 sebagai guru dengan uji t menggunkan SPSS 16.0 for windows. Adapun hasil analisis uji $\mathrm{t}$ dapat dilihat pada tabel 3 .

Tabel 3 Hasil uji statistik ttes keamanan terhadap perencanaan karir

\begin{tabular}{|c|c|c|c|}
\hline \multirow{2}{*}{\multicolumn{2}{|c|}{ Model }} & $\begin{array}{l}\text { Unstandardized } \\
\text { Coefficients }\end{array}$ & \multirow{2}{*}{$\begin{array}{c}\text { Standardized } \\
\text { Coefficients } \\
\text { Beta }\end{array}$} \\
\hline & & Std. Error & \\
\hline \multirow[t]{2}{*}{1} & (Constant) & 2.051 & 6.879 \\
\hline & keamanan & .176 & -.202 \\
\hline & $\begin{array}{l}\text { Berdasarkan hasil perhitun } \\
\text { atas, menunjukan bahwa ti } \\
\text { ggaruh secara parsial yang } \\
\text { jar karir (charier anchor) dil } \\
\text { amanan terhadap perencana } \\
\text { hasiswa Jurusan Pendidikan } \\
\text { gkatan } 2013 \text { sebagai guru. } \\
\text { Injukkan dengan thitung }=-0.20 \\
669 \text { atau sig value }=0,840>0 \\
\text { i diatas menunjukkan bahwa do } \\
\text { rrier anchor) dilihat dari keama } \\
\text { mberikan pengaruh }\end{array}$ & $\begin{array}{l}\text { gan tabel } \\
\text { dak ada } \\
\text { signifikan } \\
\text { ihat dari } \\
\text { an karir } \\
\text { Ekonomi } \\
\text { Hal ini } \\
2<t_{\text {tabel }} \\
x=0.05 \text {. } \\
\text { asar karir } \\
\text { nan tidak } \\
\text { terhadap }\end{array}$ & $\begin{array}{l}\text { perencanaan karir mahasiswa Jurusan } \\
\text { Pendidikan Ekonomi Angkatan } 2013 \\
\text { sebagai guru. Dengan demikian hipotesis } \\
\text { ketiga yang diajukan dalam penelitian ini } \\
\text { tidak dapat diterima. } \\
\text { Pengaruh dasar karir (carrier } \\
\text { anchor) dilihat dari kreativitas terhadap } \\
\text { perencanaan karir mahasiswa Jurusan } \\
\text { Pendidikan Ekonomi angkatan } 2013 \\
\text { sebagai guru dengan uji t menggunkan } \\
\text { SPSS 16.0 for windows. Adapun hasil } \\
\text { analisis uji t dapat dilihat pada tabel } 4 .\end{array}$ \\
\hline
\end{tabular}


Tabel 4 Hasil uji statistik $t_{\text {tes }}$ kreativitas terhadap perencanaan karir

\begin{tabular}{|c|c|c|c|c|c|c|}
\hline \multirow{2}{*}{\multicolumn{2}{|c|}{ Model }} & \multicolumn{2}{|c|}{$\begin{array}{c}\text { Unstandardized } \\
\text { Coefficients }\end{array}$} & \multirow{2}{*}{$\begin{array}{c}\text { Standardized } \\
\text { Coefficients } \\
\text { Beta }\end{array}$} & \multirow[t]{2}{*}{$\mathrm{T}$} & \multirow[t]{2}{*}{ Sig. } \\
\hline & & B & Std. Error & & & \\
\hline \multirow[t]{2}{*}{1} & (Constant) & 11.977 & 2.212 & & 5.414 & .000 \\
\hline & kreativitas & .059 & .072 & .101 & .810 & .421 \\
\hline \multicolumn{4}{|c|}{$\begin{array}{l}\text { Berdasarkan hasil perhitungan tabel } \\
\text { di atas, menunjukan bahwa tidak ada } \\
\text { pengaruh secara parsial yang signifikan } \\
\text { dasar karir (charier anchor) dilihat dari } \\
\text { kreativitas terhadap perencanaan karir } \\
\text { mahasiswa Jurusan Pendidikan Ekonomi } \\
\text { Angkatan } 2013 \text { sebagai guru. Hal ini } \\
\text { ditunjukkan dengan thitung }=0.810<t_{\text {tabel }}\end{array}$} & \multicolumn{3}{|c|}{$\begin{array}{l}\text { nilai diatas menunjukkan bahwa dasar karir } \\
\text { (carrier anchor) dilihat dari kreativitas tidak } \\
\text { memberikan pengaruh terhadap } \\
\text { perencanaan karir mahasiswa Jurusan } \\
\text { Pendidikan Ekonomi Angkatan } 2013 \\
\text { sebagai guru. Dengan demikian hipotesis } \\
\text { keempat yang diajukan dalam penelitian ini } \\
\text { tidak dapat }\end{array}$} \\
\hline
\end{tabular}
$=1,669$ atau sig value $=0,421>\alpha=0.05$.

Tabel 5 Hasil uji statistik $t_{\text {tes }}$ kebebasan terhadap perencanaan karir

\begin{tabular}{|c|c|c|c|c|c|c|}
\hline & \multirow{3}{*}{ Model } & \multirow{2}{*}{\multicolumn{2}{|c|}{$\begin{array}{l}\text { Unstandardized } \\
\text { Coefficients }\end{array}$}} & \multirow{3}{*}{$\begin{array}{c}\text { Standardized } \\
\text { Coefficients } \\
\text { Beta }\end{array}$} & \multirow{3}{*}{$\mathrm{T}$} & \multirow{3}{*}{ Sig. } \\
\hline & & & & & & \\
\hline & & $B$ & Std. Error & & & \\
\hline \multirow[t]{2}{*}{1} & (Constant) & 6.620 & 2.354 & & 2.812 & .007 \\
\hline & kebebasan & .330 & .107 & .363 & 3.088 & .003 \\
\hline
\end{tabular}

Berdasarkan hasil perhitungan tabel diatas, menunjukan bahwa ada pengaruh secara parsial yang signifikan dasar karir (charier anchor) dilihat dari kebebasan terhadap perencanaan karir mahasiswa Jurusan Pendidikan Ekonomi Angkatan 2013 sebagai guru. Hal ini ditunjukkan dengan $t_{\text {hitung }}=3,088>t_{\text {tabel }}=1,669$ atau sig value $=$

\section{Pembahasan}

Berdasarkan hasil penelitian diperoleh bahwa dasar karir (carrier anchor)dilihat dari kemampuan manajerial tidak memberikan pengaruh yang signifikan terhadap perencanaan karir mahasiswa Jurusan Pendidikan Ekonomi angkatan 2013 sebagai guru. Hal ini berarti dasar karir (carrier anchor) dilihat dari kemampuan manajerial tidak memiliki peranan dalam proses perencanaan karir mahasiswa untuk menjadi seorang guru. Temuan ini berbeda dengan pendapat yang diajukan oleh Edgar Schein dalam Dessler (2000) yang menyatakan bahwa dasar karir (carrier anchor) merupakan motiv yang $0,003>\alpha=0.05$. nilai diatas menunjukkan bahwa dasar karir (carrier anchor) dilihat dari kebebasan mendorong perencanaan karir mahasiswa Jurusan Pendidikan Ekonomi Angkatan 2013 sebagai guru. Dengan demikian hipotesis kelima yang diajukan dalam penelitian ini tidak dapat diterima.

mendasari seseorang memilih suatu karir yang salah satunya adalah kemampuan manajerial. Kemampuan manajerial merupakan keahlian dalam menjalankan fungsi manajemen. Dalam kemamapuan manajerial ada 7 aspek yang dijadikan tolok ukur yakni, kepemimpinan, motivasi, komunikasi, pengambilan keputusan, kewirausahaan, pengalaman dan keterampilan manajerial sesuai dengan pendapat yang diajaukan Ginting (2000). Jika dilihat pada keseharian mahasiswa Jurusan Pendidikan Ekonomi angkatan 2013, jiwa pemimpin sangat sulit untuk ditemui. Hal ini ditunjukkan dengan sikap 
mereka yang kurang mampu dalam mengarahkan teman dan memembagi tugas antar teman. Hal ini ditunjukkan oleh data yang dikumpulkan peneliti dengan kuesioner.

Motivasi yang mereka miliki untuk menjadi seorang guru sangat terbatas, hal ini ditunjukkan dengan kekhawatiran yang mereka miliki mengenai sikap siswa yang akan mereka hadapi saat menjadi seorang guru. Hanya beberapa dari mereka memiliki dorongan dari orang disekitarnya untuk menjadi seorang guru. Kesejahteraan guru yang terjamin menjadi salah satu dorongan mereka merencanakan karir sebagai guru. Untuk berkomunikasi masih banyak diantara mahasiswa Jurusan Pendidikan Ekonomi angkatan 2013 yang menemui kesulitan. Mereka masih kesulitan untuk berkomunikasi dengan orang yang lebih tinggi jabatannya, misalkan dengan dosen ataupun beberapa pegawai administrasi yang ada dilingkungan kampus. Komunikasi searah diantara mereka masih sering menemui hambatan hal ini sering mengakibatkan kesalahan penafsiran atas suatu informasi yang diberikan oleh teman sebaya. Dilihat dari segi pengalaman mengajar sebagai seorang guru, mereka hanya memperoleh dari keikutsertaanya dalam program PPL-Real. Dan saat pelaksanaan mereka banyak menemui hambatan terutama hambatan yang berhubungan dengan komunikasi dengan guru pamong maupun dengan siswa yang mereka ajar.

Dalam mengambil keputusan, mahasiswa Jurusan Pendidikan Ekonomi angkatan 2013 hanya beberapa yang memilih untuk berkarir sebagai guru. Hal ini di karenakan Jurusan Pendidikan Ekonomi tidak hanya membekali mahasiswa dengan kompetensi untuk menjadi guru tetapi juga dengan kompetensi lainnya yang mendukung untuk berkarir di bidang non keguruan seperti kompetensi untuk menjadi wiraswata dan juga bekerja pada bidang ekonomi seperti perbankan sesuai dengan profil lulusan pada Buku Pedoman Studi Fakultas Ekonomi Undiksha. Jika dari segi kewirausahaan, banyak mahasiswa Jurusan Pendidikan Ekonomi angkatan
2013 yang belum menunjukkan sikap ulet, tekut, disiplin dan pekerja keras. Ini ditunjunkan dengan kebiasaan mahasiswa dalam mengerjakan tugas perkuliahan. Dalam mengerjakan tugas mereka lebih sering mengandalkan jawaban dan tugas yang dikerjakan oleh rekannya dan lebih sering mengerjakan tugas apabila sudah kepepet waktu pengumpulan.

Dasar karir (carrier anchor) dilihat dari kemampuan teknis tidak berpengaruh signifikan terhadap perencanaan karir mahasiswa Jurusan Pendidikan Ekonomi sebagai guru. Ini menunjukkan bahwa mahasiswa dalam merencanakan karir sebagai guru tidak mempertimbangkan kemampuan teknis sebagai dasar. Hal ini berbeda dengan pendapat Edgar Schein dalam Dessler (2000) yang menyatakan bahwa motiv kedua yang digunakan untuk memilih suatu karir adalah kemampuan teknis. Menurut Robert R. Katz (dalam Moenir, 2008:188) mendefinisikan kemampuan teknis sebagai pengetahuan dan penguasaan kegiatan yang bersangkutan dengan cara ataupun proses dan prosedur yang menyangkut pekerjaan dan alat-alat kerja. Mahasiswa Jurusan Pendidikan Ekonomi angkatan 2013 tidak hanya dibekali dengan kemampuan dan ilmu keguruan melainkan dibekali kompetensi untuk menjadi wiraswasta ataupun pengkaji bidang ekonomi. Sehingga mereka tidak hanya memiliki pengetahuan mengenai prosedur dan alat kerja yang dipergunakan oleh seorang guru melainkan juga memiliki pengetahuan menyangkut alat kerja seorang wiraswasta ataupun praktisi di bidang ekonomi sesuai dengan profil lulusan yang terdapat dalam Buku Pedoman Studi Fakultas Ekonomi Undiksha.

Dasar karir (carrier anchor) dilihat dari keamanan tidak berpengaruh signifikan terhadap perencanaan karir mahasiswa Jurusan Pendidikan Ekonomi sebagai guru. Ini menunjukkan bahwa aman atau tidaknya sebuah karir tidak mempengaruhi perencanaan karir mahasiswa Jurusan Pendidikan Ekonomi. Hal ini berbeda dengan pendapat Ivancefich (2007) yang menyatakan bahwa dasar karir adalah lima 
motiv yang digunakan untuk memilih sebuah karir dan salah satu motiv tersebut adalah keamanan. Hal ini dikarenakan dengan profil lulusan yang terdapat pada Buku Pedoman Studi Fakultas Ekonomi yakni adalah wirausaha dalam bidang pendidikan/pelatihan, tenaga kependidikan ekonomi dan pengkaji pendidikan ekonomi sehingga mahasiswa diajarkan berbagai kemampuan dasar yang mencakup bidang tersebut bukan hanya sebagai guru.. Dengan memiliki kemampuan dasar tersebut memberikan kemudahan mahasiswa untuk memilih karir yang diinginkan tidak terbatas hanya sebagai guru.

Dasar karir (carrier anchor) dilihat dari kreativitas tidak berpengaruh signifikan terhadap perencanaan karir mahasiswa Jurusan Pendidikan Ekonomi angkatan sebagai guru. Hal ini berarti keativitas tidak menjadi pendorong perencanaan karir yang dilakukan oleh mahasiswa. Hasil penelitian ini berbeda dengan pendapat yang diajukan oleh Mathis (2006) yang menyatakan bahwa dasar karir (carrier anchor) merupakan pijakan yang di gunakan seseorang untuk memilih sebuah karir dan salah satu pijakan tersebut adalah kreativitas. Kreativitas ditandai dengan berfikir lancar, berfikir lues, berfikir orisinal, berfikir terperinci dan menilai (Munandar, 2000). Mahasiswa Jurusan Pendidikan Ekonomi angkatan 2013 memiliki kreativitas yang tidak hanya terbatas untuk menjadi seorang guru. Hal ini dikarenakan mahasiswa telah dipersiapkan untuk menjadi wiraswasta, praktisi pendidikan di bidang ekonomi dan penelaah bidang ekonomi sehingga mereka tidak hanya terfokus untuk menjadi seorang guru. Dengan demikian maka mahasiswa bebas berkreasi sesuai minat dan bakat tanpa harus menjadi seorang guru karena telah dibekali keamampuan dasar yang diperuntukan bagi wiraswasta, praktisi dan pengamat di bidang ekonomi. Kenyataan ini diperkuat dengan profil lulusan Jurusan Pendidikan Ekonomi yang terdapat pada Buku Pedoman Studi Fakultas Ekonomi.

\footnotetext{
Dasar karir (carrier anchor) dilihat dari kebebasan berpengaruh positif
}

terhadapa perencanaan karir mahasiswa Jurusan Pendidikan Ekonomi angkatan 2013 sebagai guru. Hal ini menunjukkan bahwa mahasiswa sangat memperhatikan kebebasan yang diberikan oleh suatu karir untuk dijadikan penentu dalam memilih sebuah karir. Ini didukung oleh pernyataan yang di sampaikan oleh Sedarmayanti (2013) yang menyatakan bahwa faktor yang mempengaruhi perencanaan karir adalah dasar karir (carrier anchor) yang salah satu bagiannya adalah kebebasan. Dilihat dari keseharian mahasiswa Jurusan Pendidikan Ekonomi angkatan 2013, mereka memiliki kecenderungan untuk berfikir, bertindak, berpendapat dan berkreasi sesuai dengan kehendak mereka tanpa dibatasi oleh orang lain.

\section{SIMPULAN DAN SARAN Simpulan}

Berdasarkan hasil analisis data dan pembahasan hasil penelitian pada bab sebelumnya maka dapat ditarik bebearapa kesimpulan sebagai berikut (1) dasar karir (carrier anchor) dilihat dari kemampuan manajerial tidak berpengaruh signifikan terhadap perencanaan karir mahasiswa Jurusan Pendidikan Ekonomi angkatan 2013 sebagai guru. hal ini berarti dasar karir (carrier anchor) dilihat dari kemampuan manajerial tidak berperan dalam perencanaan karir yang dilakukan oleh mahasiswa (2) dasar karir (carrier anchor) dilihat dari kemampuan teknis tidak berpengaruh signifikan terhadap perencanaan karir mahasiswa Jurusan Pendidikan Ekonomi angkatan 2013 sebagai guru. hal ini berarti dasar karir (carrier anchor) dilihat dari kemampuan teknis tidak berperan dalam perencanaan karir yang dilakukan oleh mahasiswa (3) tidak ada pengaruh yang signifikan dasar karir (carrier anchor) dilihat dari keamanan terhadap perencanaan karir mahasiswa Jurusan Pendidikan Ekonomi angkatan 2013 sebagai guru. hal ini menunjukkan bahwa dasar karir (carrier anchor) dilihat dari keamanan tidak berperan dalam perencanaan karir mahasiswa (4) tidak ada pengaruh yang signifikan dasar karir (carrier anchor) dilihat dari kreativitas terhadap perencanaan karir mahasiswa Jurusan Pendidikan Ekonomi angkatan 
2013 sebagai guru. hal ini menunjukkan bahwa dasar karir (carrier anchor) dilihat dari kreativitas tidak berperan dalam perencanaan karir mahasiswa (5) dasar karir (carrier anchor) dilihat dari kebebasan berpengaruh positive terhadap perencanaan karir mahasiswa Jurusan Pendidikan Ekonomi angkatan 2013 sebagai guru. hal ini menunjukkan bahwa Dasar karir (carrier anchor) dilihat dari kebebasan berperan dalam proses perencanaan karir yang dilakukan oleh mahasiswa.

\section{Saran}

Berdasarkan hasil penelitian yang telah dibahas sebelumnya dan dari penarikan kesimpulan di atas, maka dapat diajukan beberapa saran sebagai berikut (1) mahasiswa disarankan dalam merencanakan sebuah karir sebagai guru agar disiapkan secara matang dengan lebih mempertimbangkan dasar karir yang mencakup kemampuan manajerial, kemampuan teknis, keamanan, kreativitas dan kebebasan. Hal ini dimaksudkan agar setelah menapaki jenjang karir tersebut mahasiswa siap secara mental dan fisik untuk berkarir menjadi guru, (2) dalam merencanakan karir mahasiswa hendaknya memperhatikan kebebasan berfikir, kebebasan bertindak, kebebasan berpendapat dan kebebasan berkreasi. Kebebebasan akan memberikan kenyamanan bagi mahasiswa setelah menapaki jenjang karir yang dipilih. Dengan memperoleh kenyamanan maka setelah berkarir kedepannya mahasiswa akan lebih mudah untuk mengembangkan karir yang sedang dijalani.

\section{DAFTAR PUSTAKA}

Alwi, Hasan. 2003. Kamus Besar Bahasa Indonesia. Jakarta: Balai Pustaka

Arikunto, Suharsimi. 2005. Prosedur Penelitian: Suatu Pendekatan Praktek. Jakarta:PT Rineka Cipta

Arsyad, Lincolin. 2008. Ekonomi Manajerial. Yogyakarta: BPFE
Clegg, P. 2008. Kreatif dan Berfikir Kritis. Jakarta: PT Rineka Cipta

Dessler, Gary. 2000. Manajemen Personalia Edisi Revisi. Jakarta: Erlangga

Ginting, Atom. 2000. Manajemen Personalia. Bandung: Refika Aditama

Handoko, $\begin{gathered}\text { Hani. } 2003 . \quad M a n a j e m e n . \\ \text { Yogyakarta: BPFE }\end{gathered}$

Hasan, lqbal. M. 2012. Pokok-Pokok Materi Statistik 2 (Statistik Inferinsial). Jakarta: Bumi Aksara

Idrus. 2009. Statistic Imperensial. Jakarta: PT Rineka Cipta

Ivancevich, Jhon M. 2001 . Manajemen Sumber Daya Manusia. Jakarta: Tim Indeks Kelompok Gramedia

Mangkunegara. 2002. Manajemen Sumber Daya Manusia. Jakarta: Erlangga

Mathis, Robert L. 2006. Manajemen Sumber Daya Manusia. Tim Indeks Kelompok Gramedia

Moenir, A.S. 2008. Manajemen Pelayanan Umum. Jakarta: Bumi Aksara

Munandar, SCU. 2009.Pengembangan Kreativitas Anak Berbakat. Jakarta: PT. Rineka Cipta

Mustari, Mohamad. 2012. Pengantar Metode Penelitian. Yogyakarta: LaksBang Pressindo

Rivai, Veitzhal 2003. Manajemen Sumber Daya untuk Perusahaan. Jakarta: PT Raja Grafindo Persada

Robbins, Stephen P. 2002. Perilaku Organisasi. Jilid I. Jakarta: Indeks Kelompok Gramedia

Sangadji, Mamang. 2010. Metodelogi Penelitian. Yogyakarta: Andi Yogyakarta 
Sastradipoera, Komarudin. 2002. AsasAsas Manajemen Perkantoran. Bandung: Kappa Sigma

Sedarmayanti. 2013. Manajemen Sumber Daya Manusia. Bandung: Refika Aditama

Siagian, Sondang P. 2008. Manajemen Sumber Daya Manusia. Cetakan ke 16. Jakarta: Bumi Aksara

Sudijono, Anas. 2012. Pengantar Statistik Pendidikan. Jakarta: PT Raja Grafindo Persada

Sugiarto, Meilan.2007. Manajemen Sumber Daya Manusia, cetakan pertama. Ardana Media: Yogyakarta.

Suryana. 2003. Kewirausahaan: Membangun Usaha Sukses. Jakarta: Salemba Empat

Thoha, Miftah. 2003. Birokrasi dan Politik di Indonesia. Jakarta: Raja Grafindo Persada 